\title{
The Berkeley School of Political Theory as Moment and as Tradition
}

\author{
Dean Mathiowetz, University of California, Santa Cruz
}

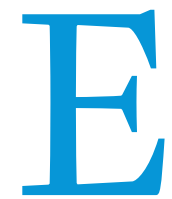
ach article in this rich symposium draws out something crucial in the material conditions, personal relationships, historical conjectures, and shadows of influence that together made political theory at the University of California, Berkeley, a highly distinctive endeavor in the 1960 s and afterwards. Because the whole is more than the sum of its parts, reading the articles together reveals a series of events, relationships, ideas, and responses to these-over many years and multiple generations of scholars-for which the term "school" seems both apt and altogether too static. What is more, to make sense of the question of the "Berkeley school"-whether, when, and whom-we also must necessarily grapple with the question of what exploring these questions means to us, and who we even are who ask or seek answers to them. It turns out that the kinds of theorizing and teaching that this symposium identifies with the "Berkeley school" are distinctively oriented to answering these questions.

Taken as a whole, this symposium raises, attempts to answer, and-in so doing-raises anew the question of why and how it remains compelling to think of all of this as a "school" today. My own contention is that it is most illuminating to understand the Berkeley school in terms similar to those that students aligned with it would use to explore the political dimensions of a community-that is, as open to and supportive of contestation around its boundaries and values. In that way, the Berkeley school is at its core a "tradition" of connecting political inquiry into the nature of participation and democracy to practices of teaching. This tradition counts a certain founding "moment" at Berkeley as one of its necessary and necessarily ambivalent beginnings, a moment whose meaning too is ambivalent and contested. The Berkeley school matters today, I argue, because of the examples of success and failure it presents in making the connection between democratic community and pedagogy, as well as in the inspiration and caution it offers to political theorists who remain dedicated to the enterprise of connecting democratic aspirations to their teaching.

Before turning directly to that claim, I explore the "whole" of this symposium by way of the insights that the articles together provide about the historical period in which Berkeley theory came to resemble a school; the question of who formed or belonged to it; and the question of what it was about-the kinds of questions about historical, personal, and ideational boundaries to which the notion of a "school" directs us, and which-in a somewhat ascending manner-lead us to the matter of Berkeley as a community of scholarship today.
As for spatial boundaries, the answer to that question seems presupposed by the political science department at UC Berkeley. However, the self-evidence of Berkeley as the "place" of the Berkeley school is possibly misleading, given the importance of a Berkeley school in diaspora, a topic to which I return.

To begin: When was Berkeley a "school"? Events noted in the symposium articles range from the first Rockefeller grant for political theory awarded to Berkeley's political science department in 1956 to contributor Brian Weiner's arrival for graduate study in 1983. To this I might add my own sense and imagination of Berkeley as a distinctive place to undertake graduate work in political theory when I arrived in 1995long after its "school" moment had passed-and a sense of inheritance that remained even then in the corridors of Barrows Hall. I argue by way of synthesis that the articles hint at ways that Berkeley remains a school-albeit in diasporaeven today and that this is the context in which the question of the Berkeley school ultimately takes its bearing and meaning. However, in most accounts-especially in Terence Ball's and Emily Hauptmann's articles-the period from 1963 to 1969 stands out; it is this period that I call the Berkeley school moment, as distinct from the Berkeley school tradition that it catalyzed. The Berkeley school moment begins with John H. Schaar and Sheldon Wolin's attack on Leo Strauss in 1963 and the radicalization of some Berkeley theorists by the Free Speech Movement the following year. We learn that whereas Schaar and Wolin went on to articulate an image of political theory as distinct from philosophy and, eventually, social science-and, as Hauptmann describes, along the way envisioned a program in political theory distinct from political science yet connected to sociology, history, and literature-Norman Jacobson briefly joined philosopher Joseph Tussmann's Experimental College. Some of this college's features (e.g., small classes and the absence of grades) mirrors the founding ethos of UC Santa Cruz, to which Schaar and Wolin moved in the early 1970s, at which point the core Berkeley school moment apparently came to an end (or fled the scene of hostilities). Even this compact history suggests that Berkeley theory, as a "school," experienced its moment as a period of intense turbulence and change-hardly the consolidation and coherence one might ordinarily expect of a school.

Who was "in" the Berkeley school, particularly during its moment? A number of figures recur in this symposium's articles but, as I read it, two stand out, both in their relationship to one another and others' relationship to them (and to their friendship). They are, of course, Schaar and Wolin, whose 
joint efforts in several projects-the critique of Strauss, the imagined program in political theory, the rescue of Jacobson's promotion to full professor, even their decampment to Santa Cruz-are situated at the center of most narratives about the Berkeley "school." Other figures matter, of course, and not only in relation to Schaar and Wolin but also never (in the account presented here) entirely absent a relation to Schaar and Wolin. More precisely, the other figures appear in these narratives in relation to the possibilities and conflicts they faced and essential to any "school" in the ordinary sense and in multiple ways important to Berkeley in the 1960 s and its relevance today. Yet, this flipped image also complicates Gunnell's account of the Berkeley school's limited horizon; Pitkin, for example, approached many of the themes and materials he describes as "off the agenda" of the Berkeley school (understood, in the topdown image, in terms of Wolin and Schaar). Rogin addressed many other themes that Gunnell does not mention, among them race and political demonology. Again, in this image of a

\section{I argue by way of synthesis that the articles hint at ways that Berkeley remains a school-albeit in diaspora-even today and that this is the context in which the question of the Berkeley school ultimately takes its bearing and meaning.}

engendered in their attempts to define the enterprise of political theory relative to the few spaces available for political thinking in a large public university. These other people include friends and students of Schaar and Wolin who themselves taught at Berkeley, such as Jacobson, Hanna Fenichel Pitkin, and Michael Rogin, and many other students of all of these figures, including (of course) most of the contributors to this symposium. To my thinking, it is most productivenot to mention consistent with images of the Berkeley school that emerge across the symposium-to flip the notion of the school so that it is not about the teachers and their lessons but instead about the students and their learning. Indeed, this image is consistent with the way we understand the importance of teaching not only to early figures such as Jacobson, Schaar, and Wolin but also to their students, and their students' students, and so on. Thus, we begin our own movement from the Berkeley school moment to a Berkeley school tradition.

Last, what was the Berkeley school about? Were we to think of a school in its top-down image and primarily in terms of its intellectual tenets or orientation? Thus, some of the contributions to this symposium suggest that Berkeley-particularly in its moment-was an anti-school. First, several of our contributors note the sharp and not especially complex antagonism to Strauss and Straussian political philosophy that catalyzed important relationships and moments at Berkeley in the 1960s. However, from the point of view of positive "tenets," the sense of what Berkeley theorists were for remains broad to the point that it is unclear how distinct Berkeley was from other non-Straussian (and even some quasi-Straussian) $\mathrm{PhD}$ programs and approaches at the time. Some tenets offered in the articles are unflattering to the idea of Berkeley theory, including Gunnell's account of some figures' moralism or reluctance to change their views. We learn that the Berkeley theorists were initially engaged by what they viewed as the openness and pluralism of social science approaches to politics but later (perhaps in response to the ascendance of behavioralism) were more oriented to an interdisciplinary pluralism. Perhaps clearest among the orientations of Berkeley as a school-and again consistent with the flipped image of the school-we encounter in these articles (especially Weiner's) is the theorists' emphasis on pedagogy, which is
Berkeley school, we encounter a tradition that both refers to and seeks to depart from its moment-an appropriate tension for a community of scholars for whom questions of founding and authority were and remain so salient.

I believe it is within this flipped model of the school and its pedagogy that we can most aptly locate Tracy Strong's description of the "architecture" of the Berkeley approach, one that he describes as a "complex...tradition of thought." Would I be exceeding or encapsulating Strong's characterization of this tradition by identifying it with a certain, self-consciously left appropriation of Aristotelian political theorizing? We might further identify the Berkeley approach, as Robyn Marasco does, by its "distinctive way of assembling a historical canon around a contemporary political problem" that brings together "a voice of radical protest" and "a theoretical practice attuned to the future and fate of the demos" (Marasco 2017). This complex tradition of Berkeley-style theorizing strikes me as a profoundly helpful approach to political thinking. Certainly, this prejudicial view reflects my own schooling in this tradition. As an undergraduate at the University of Minnesota and later as a graduate student at Berkeley in the late 1990s, nearly all of my teachers had direct connections to Schaar, Wolin, or their students. (The lone exception was a student of Benjamin Barber.) I now teach in the department where Wolin taught briefly and Schaar taught through his last year, at a university (I refer, of course, to UC Santa Cruz) the founding ethos of which still chafes against the modern reality of the university as an organ of corporate R\&D and a neoliberal marketplace for credentials.

Thus, I come to this symposium as one for whom the Berkeley school has always been a matter of traces and a question about relating the present and the past. It has always been about the fundamental ambivalence of a "founding moment" and carried the question of what to do with it. From such a perspective, the Berkeley "tradition"-a term I invoke (admittedly naively) as a helpful way of characterizing this school in diaspora, over multiple generations-was crucially about Berkeley students integrating and contesting its foundational ideas and working through the conflicts of its moment. Thus, there is irony in hints throughout the articles of wounded unwillingness to return to the scene of institutional conflicts 
that the Berkeley school "moment" engendered. They must have been painful indeed, as the conflicts and defeats hidden within foundings always are.

My point in invoking Berkeley as a tradition, however, is not to tether it to this moment or these conflicts. Instead, I think that this notion of a tradition untethers the possibilities of Berkeley from these conflicts as well as the relatively static image of a "school"-a time and a place, a constellation of exceptional people, a set of ideas-and brings them into the present, rendering them something in which we and our students can share. If we emphasize the image of a school as a living community, a Berkeley school can be understood as a community of political thinkers who are committed to an image of politics as the activity of everyday people that anyone can enter into, participate in, and take responsibility for. Such an image undergirds the "Berkeley thesis" that Strong limns and the distinctive pedagogy depicted by Weiner. of many theorists with whom I shared Berkeley seminar classrooms and hallway conversations during my own graduate days there. Moreover, the diaspora image casts a wider net of colleagues whose association with Berkeley-style teaching appears in their own intellectual trajectories and, more important, whose scholarship bears traces of Berkeley-school themes. Consider, merely as examples, John Wallach, who followed Wolin from Santa Cruz to Princeton; Wendy Brown, also a student at Santa Cruz and then of Wolin's at Princeton, now teaching at UC Berkeley; Patchen Markell, who as an undergraduate studied with Pitkin and Rogin there; Jason Frank and Cristina Beltrán, students of Schaar and Euben at UC Santa Cruz. Some of these scholars might resist my identification of them with the Berkeley tradition, and so many others could be affirmatively mentioned. I suggest them not in the interest of drawing the boundary but instead to invite the reader's own contemplation about where the concerns,

\section{My point in invoking Berkeley as a tradition, however, is not to tether it to this}

moment or these conflicts. Instead, I think that this notion of a tradition untethers the possibilities of Berkeley from these conflicts as well as the relatively static image of a "school"- a time and a place, a constellation of exceptional people, a set of ideas - and brings them into the present, rendering them something in which we and our students can share.

After all, the articles in this symposium make it amply clear that there is such a school today: in the memory, the imagination, and the lore of political theory, as we can trace it through and beyond the scholars who were connected to Berkeley political theory in the 1960s, 1970s, and early 1980 s. That it should would be rather surprising if the Berkeley school were confined to its moment. The number of those who passed through Berkeley political science in those decades (as well as the brief six-year period in which Wolin, Schaar, and Jacobson were all actively teaching at Berkeley) and who remained active in the field afterward turn out to be relatively few. In addition to some of our symposium authors, they include Richard Ashcraft, Peter Euben, Sarah Shumer, George Shulman, Joshua Miller, Linda Zerilli, Mary Dietz, Jennifer Ring, John Seery, and others, some of whom work in fields outside of political science. All of these scholars' work, I think, bears the traces of Berkeley commitments outlined in the symposium articles. Some of these theorists' writing and teaching directly and (I think) crucially address as well the questions of gender and race-opened in the Berkeley milieu by Pitkin and Rogin-that are enduringly important for evaluating and realizing the possibility of American democracy.

The broader image, however, of the school-in-diaspora draws our attention to a wider community the boundaries of which are necessarily indistinct. Therefore, they include later generations of Berkeley students, such as Jacqueline Stevens, James Martel, Jennifer Culbert, Alyson Cole, and Keally McBride. I find Berkeley-inspired themes in the work problematics, and orientations of the Berkeley tradition-as they appear in this symposium-appear today in the wider world of political theorizing. Moreover, perhaps to provoke reflection on what is at stake in exploring such a diaspora.

I conclude by reflecting on that final matter: What is at stake? Surely, this is the question underlying each article and the symposium of which they are a part. My sense of the answer, as it has developed across my work with the symposium authors and their articles, has to do with the contrast that the "Berkeley-school" affiliation offers to much of how our field has been and remains organized since its denouement with political science in the middle of the twentieth century. Theorizing that resonates with the tradition of the Berkeley school can be found across genres of political theorizing. It works not only within historical approaches and contemporary theorizing but also across them. It speaks not from within but rather across-and sometimes orthogonally to-the "debates" that cycle through our journals. Whatever is the stature of figures such as Wolin in the Berkeley school moment, the tradition of Berkeley-school theorizing demands fidelity to no particular set of texts or manner of interpretation. Whereas the tradition, with its themes and characteristic commitments, is most visible in scholarly writing, it also is revealed in the classroom. In both of these spaces, it encourages a fidelity to its sources (most often, the text) as well as a connection to political worlds beyond the classroom or academic debate-bringing the text and the world together through shared practices of reading and writing. Indeed, theory 
pedagogy in the Berkeley tradition understands "community" as crafted precisely from these activities: a shared but contestable (and contested) relationship to things-in-common that matters to wider worlds of power and participation. In my view, what is at stake in the question of a Berkeley school today resides in whether and how our scholarship and teaching, thus brought together, can counteract the juggernaut of academic professionalization in the neoliberal university. It speaks to how scholars with secure institutional status might keep open spaces for younger scholars to work outside of tightly defined debates, canons, and approaches to political theorizing. It speaks to how theorists must continue to connect our work as scholars to our work in the classroom and to the work of politics. For all who share these concerns and commitments, the question of a Berkeley school-and the vital traces of its tradition-is one that matters.

\section{REFERENCE}

Marasco, Robyn. 2017. "Sheldon Wolin's Theoretical Practice: The Epic as Form.” Contemporary Political Theory doi:10.1057/s41296-017-0090-6

\section{SYMPOSIUM CONTRIBUTORS}

Terence Ball is Professor Emeritus of Political Science and Philosophy at Arizona State University. He is author of, among other works, Transforming Political Discourse (1988), Reappraising Political Theory (1995), and a mystery novel, Rousseau's Ghost (1998), and editor or co-editor of others, including The Cambridge History of TwentiethCentury Political Thought (2003). He is also co-author (with Richard Dagger and Daniel O'Neill) of the textbook Political Ideologies and the Democratic Ideal (1oth edition, 2017). He can be reached at tball@asu.edu.

John G. Gunnell is Distinguished Professor, Emeritus, Department of Political Science, at the State University of New York at Albany and currently a Research Associate at the University of California at Davis. He focuses on various aspects of political theory with special emphasis on the history and philosophy of social science. Recent work includes John G. Gunnell: History, Discourses, and Disciplines, ed. Christopher C. Robinson (2016) and Social Theory After Wittgenstein and Kuhn Leaving Everything As It Is (2014). He may be reached at jgunnell@albany.edu

Emily Hauptmann is Professor of Political Science at Western Michigan University. She is also executive co-director for the Association of Political Theory. She may be reached at Emily.hauptmann@wmich.edu.

Dean Mathiowetz is Associate Professor and Chair of Politics at the University of California at Santa Cruz. He is author of Appeals to Interest: Language and the Shaping of Political Agents and numerous articles on conceptual history and political economy. He is also editor of Hanna Fenichel Pitkin: Politics, Justice, Action. His current writing projects seek to recover luxury as a central concept in critical political economy. He may be reached atdpmath@ucsc.edu.

Tracy B. Strong is presently Professor of Political Theory and Philosophy at the University of Southampton (UK) and UCSD Distinguished Professor, emeritus. His most recent book is Politics without Vision: 'Thinking without a Banister' in the Twentieth Century. From 1990 to 2002 he was editor of Political Theory, an international journal of political philosophy.He may be reached at tstrong@ucsd.edu.

Brian A. Weiner is associate professor at the University of San Francisco. He specializes in political theory and public law. He is the author of Sins of the Parents: The Politics of National Apologies in the United States (Temple University Press, 2005). He may be reached at weinerb@usfca.edu. 